\title{
Bibliometric Studies and Worldwide Research Trends on Global Health
}

\author{
Esther Salmerón-Manzano ${ }^{1}$ and Francisco Manzano-Agugliaro ${ }^{2, *(\mathbb{D})}$ \\ 1 Faculty of Law, Universidad Internacional de La Rioja (UNIR), Av. de la Paz, 137, 26006 Logroño, Spain; \\ esther.salmeron@unir.net \\ 2 Department of Engineering, University of Almeria, ceiA3, 04120 Almeria, Spain \\ * Correspondence: fmanzano@ual.es; Tel.: +34-950-015346; Fax: +34-950-015491
}

Received: 6 August 2020; Accepted: 7 August 2020; Published: 9 August 2020

\begin{abstract}
Global health, conceived as a discipline, aims to train, research and respond to problems of a transboundary nature in order to improve health and health equity at the global level. The current worldwide situation is ruled by globalization, and therefore the concept of global health involves not only health-related issues but also those related to the environment and climate change. Therefore, in this Special Issue, the problems related to global health have been addressed from a bibliometric approach in four main areas: environmental issues, diseases, health, education and society.
\end{abstract}

Keywords: COVID-19; asthma; pulmonary disease; HIV/AIDS; diabetes; medicinal plants; musculoskeletal risks; obesity; microplastics; climate change; wastewater treatment; patents; social networks

\section{Introduction}

Science aims to answer questions, and from a pragmatic approach, science can be understood as a resolution of problems in our society. Science cannot be considered an independent activity, and therefore, it must be remembered that prior studies have been carried out in any given scientific field. Combining scientific aspects with documental aspects gives rise to a certain type of scientific work: scientometric, bibliometric, and informetric studies. These take different titles according to the final approach of the work, such as the following: examining the scholarly literature, evolution, and new trends; worldwide research trends; mapping of the knowledge base; visualizing the knowledge structure; analysis of global research; publication trends; knowledge domain visualization. Scientific literature is losing its relevance more and more quickly, but the aging of literature is not uniform for all scientific subjects. This means that being up to date in a scientific field requires bibliometric studies through which new trends are revealed when undertaking scientific studies of interest to the community. Two topics of special interest to society today are environmental research and public health, and within these larger topics are sub-topics related to global health. Global health, in a broad context, refers to improving health worldwide, reducing disparities, and protecting against global threats that do not consider national borders. This Special Issue aims to provide a global view of all of these global health issues, and through bibliometric studies, we believe that this objective can be achieved. Therefore, articles reviewing the state of the art in any of these fields, bibliometric or scientometric studies, and research articles dealing with a global perspective are welcome.

\section{Publications Statistics}

The summary of the call for papers for this Special Issue on the 28 manuscripts submitted: rejected (12; $43 \%)$ and published $(16 ; 67 \%)$. 
The submitted manuscripts come from many countries and are summarized in Table 1. For this statistic only the first affiliation of the authors has been considered, in which it gives the opportunity to observe 66 authors from nine countries. Note that it is common for a manuscript to be signed by more than one author and for authors to belong to different affiliations. The average number of authors per published manuscript in this Special Issue was seven authors.

Table 1. Statistics of authors by country.

\begin{tabular}{cc}
\hline Country & Authors \\
\hline Spain & 20 \\
China & 18 \\
Vietnam & 6 \\
USA & 2 \\
Singapore & 2 \\
Canada & 1 \\
Sweden & 1 \\
Australia & 2 \\
UK & 1 \\
Total & 53 \\
\hline
\end{tabular}

\section{Authors' Affiliations}

There are 23 different affiliations of the authors. Note that only the first affiliation per author has been considered. Table 2 summarizes the authors and their first affiliations.

Table 2. Authors and affiliations.

\begin{tabular}{ccc}
\hline Author & First Affiliation & References \\
\hline Martinez-Perez, C. & Universidad Europea de Madrid & {$[1]$} \\
Alvarez-Peregrina, C. & Universidad Europea de Madrid & {$[1]$} \\
Villa-Collar, C. & Universidad Europea de Madrid & {$[1]$} \\
Sánchez-Tena, M. A. & Universidad Europea de Madrid & {$[1]$} \\
Li, F. & China Medical University & {$[2]$} \\
Zhou, H. & China Medical University & {$[2]$} \\
Huang, D. S. & China Medical University & {$[2]$} \\
Guan, P. & China Medical University & {$[2]$} \\
Hoang, M. T. & Duy Tan University & {$[3]$} \\
Le, H. T. & Hanoi Medical University & {$[3]$} \\
Cascajares, M. & University of Almería & {$[4]$} \\
Alcayde, A. & University of Almería & {$[4]$} \\
Pham, H. Q. & Duy Tan University & {$[5]$} \\
Salmerón-Manzano, E. & University of Almería & {$[6]$} \\
Vu, G. V. & Hanoi Medical University & {$[7]$} \\
Nguyen, C. T. & Duy Tan University & {$[7]$} \\
Wang, M. & Chengdu University of Technology & {$[8]$} \\
Liu, P. & Chengdu University of Technology & {$[8]$} \\
Zhang, R. & Chengdu University of Technology & {$[8]$} \\
Li, Z. & Chengdu University of Technology & {$[8]$} \\
Li, X. & Chengdu University of Technology & {$[8]$} \\
Hall, B. J. & Johns Hopkins University & {$[9]$} \\
Hoang, C. L. & Nguyen Tat Thanh University & {$[9]$} \\
McIntyre, R. S. & University of Toronto & {$[10]$} \\
Pham, N. M. & Curtin University & {$[11]$} \\
Vu, H. T. T. & Hanoi Medical University & \\
\hline
\end{tabular}


Table 2. Cont.

\begin{tabular}{|c|c|c|}
\hline Author & First Affiliation & References \\
\hline Nguyen, H. T. & National Institute of Nutrition & [11] \\
\hline Esteban-García, B. & University of Almería & [12] \\
\hline Agüera, A. & University of Almería & [12] \\
\hline Sánchez-Pérez, J. A. & University of Almería & {$[12]$} \\
\hline Nghiem, S. & Griffith University & [13] \\
\hline Afoakwah, C. & Griffith University & [13] \\
\hline Doan, L.P. & Nguyen Tat Thanh University & [13] \\
\hline Aparicio-Martinez, $\mathrm{P}$. & University of Cordoba & [14] \\
\hline Perea-Moreno, A. J. & University of Cordoba & [14] \\
\hline Martinez-Jimenez, M. P. & University of Cordoba & [14] \\
\hline Redel-Macías, M. D. & University of Cordoba & [14] \\
\hline Vaquero-Abellan, $\mathrm{M}$. & University of Cordoba & [14] \\
\hline Pagliari, C. & University of Edinburgh & [14] \\
\hline Gómez-Galán, M. & University of Almería & [15] \\
\hline Callejón-Ferre, Á. J. & University of Almería & [15] \\
\hline Pérez-Alonso, J. & University of Almería & [15] \\
\hline Díaz-Pérez, M. & University of Almería & [15] \\
\hline Carrillo-Castrillo, J. A. & University of Seville & [15] \\
\hline Qin F. & Dalian University of Technology Library & [16] \\
\hline $\mathrm{Du} J$. & Liaoning Ocean and Fisheries Science Research Institute & {$[16]$} \\
\hline Gao J. & Dalian University of Technology Library & [16] \\
\hline Liu G. & Liaoning Ocean and Fisheries Science Research Institute & {$[16]$} \\
\hline Song Y. & Liaoning Ocean and Fisheries Science Research Institute & [16] \\
\hline Yang, A. & Technology Center of Dalian Customs District & [16] \\
\hline Wang $\mathrm{H}$. & Ocean University of China & [16] \\
\hline Ding, $Y$. & Dalian University of Technology Library & [16] \\
\hline Wang Q. & Ocean University of China & {$[16]$} \\
\hline Tran, B. X. & Hanoi Medical University & {$[3,5,7,9-11,13]$} \\
\hline Ha, G. H. & Duy Tan University & {$[3,5,7,9-11,13]$} \\
\hline Nguyen, L. H. & Vietnam National University & {$[3,11]$} \\
\hline $\mathrm{Vu}, \mathrm{G} . \mathrm{T}$. & Nguyen Tat Thanh University & {$[3,5,7]$} \\
\hline Latkin C. A. & Johns Hopkins University & {$[3,5,7,9-11,13]$} \\
\hline Ho, C.S.H. & National University Hospital & {$[3,5,7,9-11,13]$} \\
\hline Ho, R. & National University of Singapore & {$[3,5,7,9-11,13]$} \\
\hline Phan, H. T. & Hanoi Medical University & {$[5,9,10]$} \\
\hline $\mathrm{Vu}, \mathrm{G} . \mathrm{T}$. & Nguyen Tat Thanh University & {$[5,9,10]$} \\
\hline Pham, H. Q. & Duy Tan University & {$[7,10,11,13]$} \\
\hline Nguyen, T.P. & Nguyen Tat Thanh University & {$[11,13]$} \\
\hline Garrido-Cardenas, J. A. & University of Almería & {$[4,6,12]$} \\
\hline Manzano-Agugliaro, F. & University of Almería & {$[4,6,12]$} \\
\hline
\end{tabular}

\section{Topics}

Table 3 summarizes the research conducted by the authors in this Special Issue, by identifying the areas to which they report. It was noted that they have been grouped into four main lines of research: environmental issues, diseases, health and society. They have mainly explored the issue of disease research, these have been: COVID-19, asthma, pulmonary disease, HIV/AIDS, and diabetes. Related to health, they were: medicinal plants, musculoskeletal risks, and obesity. The environmental issues were related to: microplastics, climate change, and wastewater treatment. Finally, research related to education and society: academic performance, patents, bibliometric analysis, and social networks and young people. 
Table 3. Topics for worldwide research trends on global health.

\begin{tabular}{ccc}
\hline Bibliometric Studies & Number of Manuscripts & References \\
\hline Environmental issues & 3 & {$[2,12,16]$} \\
Diseases & 6 & {$[3,5,7,9-11]$} \\
Health & 3 & {$[6,13,15]$} \\
Education and society & 4 & {$[1,4,8,14]$} \\
\hline
\end{tabular}

Author Contributions: The authors all made equal contributions to this article. All authors have read and agreed to the published version of the manuscript.

Funding: This research received no external funding.

Conflicts of Interest: The authors state that there are no conflict of interest.

\section{References}

1. Martinez-Perez, C.; Alvarez-Peregrina, C.; Villa-Collar, C.; Sánchez-Tena, M.Á. Current State and Future Trends: A Citation Network Analysis of the Academic Performance Field. Int. J. Environ. Res. Public Health 2020, 17, 5352. [CrossRef] [PubMed]

2. Li, F.; Zhou, H.; Huang, D.S.; Guan, P. Global Research Output and Theme Trends on Climate Change and Infectious Diseases: A Restrospective Bibliometric and Co-Word Biclustering Investigation of Papers Indexed in PubMed (1999-2018). Int. J. Environ. Res. Public Health 2020, 17, 5228. [CrossRef] [PubMed]

3. Tran, B.X.; Ha, G.H.; Nguyen, L.H.; Vu, G.T.; Hoang, M.T.; Le, H.T.; Latkin, C.A.; Ho, C.S.H.; Ho, R. Studies of Novel Coronavirus Disease 19 (COVID-19) Pandemic: A Global Analysis of Literature. Int. J. Environ. Res. Public Health 2020, 17, 4095. [CrossRef] [PubMed]

4. Cascajares, M.; Alcayde, A.; Garrido-Cardenas, J.A.; Manzano-Agugliaro, F. The Contribution of Spanish Science to Patents: Medicine as Case of Study. Int. J. Environ. Res. Public Health 2020, 17, 3638. [CrossRef] [PubMed]

5. Phan, H.T.; Vu, G.V.; Vu, G.T.; Ha, G.H.; Pham, H.Q.; Latkin, C.A.; Tran, B.X.; Ho, C.S.H.; Ho, R. Global Mapping of Research Trends on Interventions to Improve Health-Related Quality of Life in Asthma Patients. Int. J. Environ. Res. Public Health 2020, 17, 3540. [CrossRef] [PubMed]

6. Salmerón-Manzano, E.; Garrido-Cardenas, J.A.; Manzano-Agugliaro, F. Worldwide Research Trends on Medicinal Plants. Int. J. Environ. Res. Public Health 2020, 17, 3376. [CrossRef] [PubMed]

7. Vu, G.V.; Ha, G.H.; Nguyen, C.T.; Vu, G.T.; Pham, H.Q.; Latkin, C.A.; Tran, B.; Ho, R.; Ho, C.S. Interventions to Improve the Quality of Life of Patients with Chronic Obstructive Pulmonary Disease: A Global Mapping During 1990-2018. Int. J. Environ. Res. Public Health 2020, 17, 3089. [CrossRef] [PubMed]

8. Wang, M.; Liu, P.; Zhang, R.; Li, Z.; Li, X. A Scientometric Analysis of Global Health Research. Int. J. Environ. Res. Public Health 2020, 17, 2963. [CrossRef] [PubMed]

9. Vu, G.T.; Tran, B.X.; Hoang, C.L.; Hall, B.J.; Phan, H.T.; Ha, G.H.; Latkin, C.A.; Ho, C.S.; Ho, R. Global research on quality of life of patients with HIV/AIDS: Is it socio-culturally addressed? (GAPRESEARCH). Int. J. Environ. Res. Public Health 2020, 17, 2127. [CrossRef] [PubMed]

10. Vu, G.T.; Tran, B.X.; McIntyre, R.S.; Pham, H.Q.; Phan, H.T.; Ha, G.H.; Latkin, C.A.; Ho, R.; Ho, C.S. Modeling the Research Landscapes of Artificial Intelligence Applications in Diabetes (GAPRESEARCH). Int. J. Environ. Res. Public Health 2020, 17, 1982. [CrossRef] [PubMed]

11. Tran, B.X.; Nguyen, L.H.; Pham, N.M.; Vu, H.T.T.; Nguyen, H.T.; Phan, D.H.; Ha, G.H.; Phan, H.Q.; Nguyen, T.P.; Latkin, C.A.; et al. Global Mapping of Interventions to Improve Quality of Life of People with Diabetes in 1990-2018. Int. J. Environ. Res. Public Health 2020, 17, 1597. [CrossRef] [PubMed]

12. Garrido-Cardenas, J.A.; Esteban-García, B.; Agüera, A.; Sánchez-Pérez, J.A.; Manzano-Agugliaro, F. Wastewater treatment by advanced oxidation process and their worldwide research trends. Int. J. Environ. Res. Public Health 2020, 17, 170. [CrossRef] [PubMed]

13. Tran, B.X.; Nghiem, S.; Afoakwah, C.; Latkin, C.A.; Ha, G.H.; Nguyen, T.P.; Doan, L.P.; Pham, H.Q.; Ho, C.S.; Ho, R. Characterizing Obesity Interventions and Treatment for Children and Youths During 1991-2018. Int. J. Environ. Res. Public Health 2019, 16, 4227. [CrossRef] [PubMed] 
14. Aparicio-Martinez, P.; Perea-Moreno, A.J.; Martinez-Jimenez, M.P.; Redel-Macías, M.D.; Vaquero-Abellan, M.; Pagliari, C. A bibliometric analysis of the health field regarding social networks and young people. Int. J. Environ. Res. Public Health 2019, 16, 4024. [CrossRef] [PubMed]

15. Gómez-Galán, M.; Callejón-Ferre, Á.J.; Pérez-Alonso, J.; Díaz-Pérez, M.; Carrillo-Castrillo, J.A. Musculoskeletal Risks: RULA Bibliometric Review. Int. J. Environ. Res. Public Health 2020, 17, 4354. [CrossRef] [PubMed]

16. Qin, F.; Du, J.; Gao, J.; Liu, G.; Song, Y.; Yang, A.; Wang, H.; Ding, Y.; Wang, Q. Bibliometric Profile of Global Microplastics Research from 2004 to 2019. Int. J. Environ. Res. Public Health 2020, 17, 5639. [CrossRef]

(C) 2020 by the authors. Licensee MDPI, Basel, Switzerland. This article is an open access article distributed under the terms and conditions of the Creative Commons Attribution (CC BY) license (http://creativecommons.org/licenses/by/4.0/). 